\title{
THE RE-ESTABLISHMENT OF THE ETHIOPIA'S MONETARY AND BANKING SYSTEMS
}

\author{
ARNALDO MAURI
}

Working Paper n. 2008-11

MAGGIO 2008

U 0 I I I UNIVERSITẢ DEGLI STUDI DI MILANO

\section{Dipartimento dI SCIENZE ECONOMICHE AZIENDALI E StATISTICHE}

Via Conservatorio 7

20122 Milano

tel. ++390250321501 (21522) - fax ++390250321450(21505)

http://www.economia.unimi.it

E Mail: dipeco@unimi.it 


\title{
THE RE-ESTABLISHMENT OF THE ETHIOPIA'S MONETARY ANDBANKING SYSTEMS (1941-1963)
}

\author{
Arnaldo Mauri \\ Department of Economics, Business and Statistics \\ Università degli Studi di Milano
}

\begin{abstract}
The study is concerned with a crucial period of the banking history of Ethiopia, almost untouched so far by the specializing literature, in which the banking industry was affected by important changes. The paper describes and analyses the reconstruction process of the banking system and the reorganization of the monetary setting in Ethiopia started in 1941, when the Italian colonial rule came to an end and the country regained independence, during World War II. The terminal date of the study is the beginning of 1964, when a one-tier banking system, based on a state-owned financial institution, the State Bank of Ethiopia, gave way to a two-tiers banking system. The monetary banking reform in Ethiopia after liberation in 1941 was an event logical, inevitable and predictable. Different paths, however could had be followed at that moment. The choice in money matter was to establish a national monetary unit, the Ethiopian dollar, instead of keeping the country inside the East African shilling area. On the other hand, as far as concerns banking, it was opted for establishing a stateowned financial institution enjoying a monopolistic position in the credit market rather than for setting up a system of private banks, possibly expatriate.
\end{abstract}

\section{JEL Classification: E 42, G 21, N 27}

\section{Keywords: Ethiopia, African Banking, Banking History, Monetary Reform}

\section{Introduction}

Ethiopia, may be ranked among the longest surviving states not only in Africa, but in the whole world, its history going back to the ancient Axumite kingdom. In fact, this inland country, because of the mountainous nature of the territory and the indomitable spirit of its inhabitants, unlike most of African countries, has been able to preserve through the centuries its independence, national identity and cultural heritage. The advent of banking in Ethiopia had been marked by the establishment of the Bank of Abyssinia in 1905 (Mauri 1967; Schaefer 1992). In 1931, however, this institution was liquidated and its assets and liabilities as well as premises and staff were taken over by the new established state-owned Bank of Ethiopia. The Bank of Ethiopia, at its turn, closed its business following the occupation of the country by the Italian army (Mauri 1967, Tuccimei 1999).

The purpose of this paper, however, is to describe and analyse the reconstruction process of the Ethiopian banking system and the reorganization of the monetary setting in the country, both started in 1941, when the short-lived Italian colonial rule came to an end during World War II. The terminal date of the study is the end of 1963: on $1^{\text {st }}$ January of the following year, in fact, the one-tier banking system, based on a state-owned financial institution (the State Bank of 
Ethiopia) operating both as bank of issue as well as a commercial bank, gave way to a two-tiers banking system, with the creation of a central bank, following provisions of the imperial Proclamation $N^{\circ} .207$ of July $27^{\text {th }}, 1963$.

Historically, when one country conquers an other country, the currency brought in by the conqueror usually replaces the currency of the occupied country. This was the case of Ethiopia; twice in the laps of a quinquennium the legal tender currency was changed by conquerors. In 1936, the Italian lira had replaced the Ethiopian thaler issued by the Bank of Ethiopia and, in 1941, the currency of the defeated colonial ruler had been, at its turn, replaced by the East African shilling brought in by the British conquering army. The occupying power, however, found it more convenient in 1941 not to allow its own domestic currency, i.e. the sterling, to be legal tender in Ethiopia and, instead, to enforce the British colonial currency issued by the East African Currency Board (Mauri 2007).

The paper has three more sections. Section 2 analyses the heterogeneous monetary circulation of the country after the collapse of the Italian colonial administration and the attempts of Ethiopian authorities to reorganise the monetary setting as well as the first steps in establishing a national banking system. Section 3 deals with the re-achievement of monetary sovereignty by Ethiopia. Section 4 examines the development of the State Bank of Ethiopia and the accomplishment of the role of central bank. The paper ends with a summary of the findings and some concluding remarks in Section 5.

\section{The First Steps}

Ethiopia, after a centuries-old independence, had experienced in the second half of the 30s a short period of colonization and relative economic improvement, accompanied by an increasing use of money for transactional purposes, under Italian rule. During this lapse of time, a number of Italian banks had settled in the country and a network of 24 bank-branches, covering all the regions, was set up (Mauri 1967; De Rosa 1982; Tuccimei 1999). ${ }^{1}$

In the course of the second World War Haile Sellassie re-entered the country, in 1941, following the winning British army, and eventually Ethiopia was liberated from Italian occupation. Upon his return to the throne, the Emperor, intended to pursue the same objectives in the monetary and financial field on which were based his innovative policies implemented in the country during the early nineteen-thirties, just few years before foreign invasion. These objectives were mainly represented by the creation of a national bank, wholly Ethiopian, and by the establishment of a domestic monetary system (Mauri 1997).

However the economic and political situation of Ethiopia at that time, which continued to feel the effect of the recent hostilities, together with he British military presence, ${ }^{2}$ suggested to leave these objectives aside for the time being

\footnotetext{
${ }^{1}$ In addition, in Eritrea were operating 13 bank-branches and in Somalia 5 bank-branches for a total of 42 branch-offices in the whole Italian East Africa Empire (A.O.I.)

2 The British, who entered the Ethiopia as liberators, in the temporary absence of Ethiopian authorities, had in fact, replaced the Italian Colonial Administration in ruling the country. The political and military control as well as economic control were firmly in British hands. Ethiopia was incorporated into the British sterling area via East Africa shilling and full banking services were provided as a monopoly by a British financial intermediary, the Barclays Bank. A branch of this institution had been opened in Addis Ababa, just after liberation of the city in order to meet the immediate banking requirements (Perham 1949; Konczacki 1962). The British Military
} 
and to give, instead, priority to the reorganization of the current monetary setting. British-East African, Egyptian, Indian and Italian notes and coins as well as Maria Theresa's silver thalers, in fact, circulated side-by-side in a chaotic situation characterized by wild fluctuations of market rates of exchange, i.e. the prices of one currency in terms of another to settle demand and supply as for any other commodity traded on the market.

The Maria Theresa's thaler was an impressive-looking silver coin $(0.8333$ fine) originally struck in Vienna in the reign of the Empress Maria Theresa of Habsburg and minted thereafter for the countries of the Red Sea Littoral and for Abyssinia, but always with the same date, 1780 (Tschoegl 2001). In some areas of Ethiopia in 1941 the Austrian silver coins, being a full-bodied money, were still the most popular means, both for payments and hoarding. According to Pankhurst (1965) and other authors, this silver coin, besides its use as money, i.e. means of payment, standard of value and store of value, also performed relevant nonmonetary functions: in fact it served as jewel, as certified source of silver for melting down and even as a measure of weight (28.0668 grams).

The volatility of free market exchange rates among different currencies circulating in Ethiopia, as observed before, was high and rates differed notably from one place to the next. Furthermore, for each single monetary unit, coins were unequally valued in relation to their denomination, the intrinsic nature of specie (metal differing in silver, nickel, acmonital, copper and bronze and in finesse) and their wear (Mauri 1967).

The overall circulating medium of exchange and its qualitative make-up changed over time as a result of currencies inflows and outflows along the little watched Ethiopian borders. The intensity of these flows was at the same time cause and effect of prices of commodities and free market exchange rates variations.

Alarmed by the rapid worsening of monetary situation, Ethiopian Authorities decided to regulate without further delay the whole matter. With an initial ordinance dated September $27^{\text {th }}, 1942$ (Proclamation $\mathrm{N}^{\circ}$ 23), Ethiopian Authorities made the export of Maria Theresa's silver thalers subject to their preliminary authorization. An outpouring of the Austrian thalers from the country was going on, following a sharp rise of the price of silver on the world market.

The exchange rate of Habsburgs silver coin (a full bodied money) with the East African shilling in the free market had, in fact, exceeded that of the official exchange rate. The apex of the gap between free market exchange rate and official exchange rate occurred in 1944, when the value of the Maria Theresa's thaler in terms of silver content and based on international silver price corresponded approximately three shillings, while the official exchange rate was two shillings per thaler (Luther 1958).

An attempt to complete regulation on this matter was made by the government of Addis Ababa with a set of laws, each apparently drawn up at different time, which appeared together in the Negarit Gazeta of $31^{\text {st }}$ October 1942.

The first law (Proclamation $\mathrm{N}^{\circ}$. 31) revoked definitely the status of legal tender of the Egyptian pound and of the Indian rupee. Status of legal tender was reconfirmed, on the other hand, for East African shilling (Mauri 2007) and Maria Theresa's thaler and was given back to the Italian lira. It is worth to remind at this point that according to the preceding Notice $N^{\circ} .3$ of $7^{\text {th }}$ April 1941 issued by the

Administration was, in fact, quite reluctant to share ruling powers, chiefly in the monetary and financial field, with emerging Ethiopian authorities. 
British Military Administration and signed by General Cunningham at his headquarter in Harar, only four currencies had gained the blessing of legal tender status: the Maria Theresa's thaler, the East African shilling, the Indian rupee and the Egyptian pound. ${ }^{3}$

According the Proclamation $N^{\circ} .31$ of $31^{\text {st }}$ October 1942, all currencies outside the three given legal tender status, were to be considered foreign and to be traded only by ad hoc authorised dealers. The above-mentioned act also confirmed the ban on export of Maria Theresa thalers and - it added - of any other currency without specific authorisation (Perham 1949).

The content of this law was, however, partially contradicted by a successive act (Proclamation $\mathrm{N}^{\circ}$. 32) which gave legal tender status only to the Austrian full bodied silver coin and to the East African shilling. Italian lira, instead, was to be accepted for payments to the Public Administration for only one quarter, starting from the date the act became effective. The Italian currency was to be allowed to circulate among private parties, and to be valued on the basis of the official exchange rates, provided that liras were of a coin or, in the case of notes, of denomination not exceeding ten. A decree of the same date (Legal Notice $\mathrm{N}^{\circ}$. 10/1942) fixed the value of Maria Theresa's thaler at 1.875 East African shillings.

The obvious aim of all these enactments of the Ethiopian government was to reduce the heterogeneity of the stock of money in circulation by excluding currencies of foreign origin except those most accepted by people and those officially used in the country by British military authorities. The exclusion of Italian lira, the currency formerly introduced into the country by the collapsed Italian colonial empire, was not immediate but easily foreseeable in this context.

The official exchange rate between the East African shilling and the Maria Theresa's thaler was later modified in the Austrian silver coin's favour with a decree issued on $29^{\text {th }}$ January 1943 (Legal Notice $N^{\circ}$ 13/1943). According to new official rate, one Maria Theresa's thaler was worth two East African shillings. Eventually, on September $30^{\text {th }} 1943$, was issued the Legal Notice 32/1943 in order to regulate the outflow of East African shillings.

The results obtained by this series of measures were, however, definitely unsatisfactory, only in part owing to the lack of enforcing power of Ethiopian authorities, especially in the outlying areas. The Emperor, on the other hand, had hoped to embark upon a complete monetary reform, but his designs met with an understandable strong British resistance. The British, in fact, meant to keep Ethiopia within the monetary area of the East African Currency Board and were, if anything, inclined to make concessions in the banking industry field, which was much less interesting for them (Mauri 1967). Priority was thus given by the Emperor to the aim of creating an Ethiopian bank.

Plans to establish a bank of issue as it had been in 1931 the Bank of Ethiopia, short lived because of Italian occupation, had obviously to be set aside, at least for the moment. They were in fact conflicting with British objectives on money matter in the region. A compromise-solution calling for a the constitution of a state-owned commercial bank was necessarily opted for. Slightly less than

\footnotetext{
${ }^{3}$ Marein (1955, p. 216) states at this regard: "the said Notice contains a passage which seems to indicate that General Cunningham's power to issue such rules is derived from His Imperial Majesty". The Notice of April $7^{\text {h }} 1941$, was followed by a Notice issued by British Military Authority on April $24^{\text {th }}$, 1941, fixing official exchange rates between Italian lira and the legal tender currencies. According to this Notice, one Maria Theresa's silver thaler equalled 45 Italian liras, one East African shilling's worth was 24 Italian liras, one Egyptian pound's worth was 492 Italian liras and one Indian rupee's woth was 36 Italian liras.
} 
two months after the establishment of the Post Office, on $26^{\text {th }}$ August 1942, the law constituting the State Bank of Ethiopia (SBE) as a corporate entity was enacted (Proclamation $\mathrm{N}^{\circ}$. 21). Article 3 of the above mentioned imperial proclamation prescribed that the capital of the bank was to correspond to one million of Maria Theresa's silver thalers, the currency then in force in the country along with the East African shilling. The capital was fully subscribed by the Ethiopian Ministry of Finance.

Contacts with Barclays Bank, followed and an agreement was eventually reached in the context of a wider Anglo-Ethiopian convention, requiring the British bank, previously operating as sole bank in the country, to pull out of Addis Ababa on $15^{\text {th }}$ April of the following year relinquishing its branch to the State Bank of Ethiopia. ${ }^{4}$

The Bank's charter, published in Negarit Gazeta on $30^{\text {th }}$ November 1943 (General Notice $\mathrm{N}^{\circ}$. 18/1943), authorized it to carry out all kinds of transactions customary for commercial banks on the withdrawal of Barclays Bank and, further, gave it the power to make industrial loans. The Bank was entrusted also of the service of fiscal agent and banker of the Ethiopian government. The governance of the Bank, consisting of a Board of Directors, was to be appointed by the Imperial government.

The need to create a new financial institution, alongside the existing commercial bank, an institution fully devoted to financing the agricultural sector and rural economy was felt very early on. Following an initiative of the Ministry of Agriculture, the Agricultural Bank was thus established by an act on $29^{\text {th }}$ April 1945 (Proclamation $\mathrm{N}^{\circ}$. 75). The capital of this specialising financial institution, amounting to one million of Maria Theresa's silver thalers, was to be fully subscribed by the Ethiopian Ministry of Finance as well.

\section{The Achievement of Monetary Sove reignty}

The Addis Ababa government's firm decision to face and solve radically the monetary difficulties of the Ethiopian economy as well as to replace East African shillings with a national currency providing by this way a uniform medium of exchange for the whole country helped to accelerate the process of monetary and banking reform.

As might be expected, British resistance made tricky the implementation of Emperor's plans, but at the end these difficulties proved less strong than anticipated. It often happens that a nation's development it is determined by fortuitous circumstances, foreign as well as domestic, and by relevant events occurred in other parts of the world. The rise of cold war and United States ambitions to play a leading role also in the African continent and chiefly in a country close to the oil producing area of Arabic peninsula, pushed the British to reconsider radically their plans on the Horn of Africa.

This project gave rise to Proclamation $N^{\circ} .76$ of $29^{\text {th }}$ May 1945 , cited as the Currency and Legal Tender Proclamation, 1945. A preliminary modification of the terms of the 1942 Anglo-Ethiopian monetary agreement was, however, a pre-

\footnotetext{
${ }^{4}$ The Addis Ababa branch of Barclay's Bank had been opened in 1941.
} 
condition and a new agreement was thus reached which conferred monetary sovereignty on Ethiopia. ${ }^{5}$ British resistance to Ethiopia's exit from the East African Currency Board's monetary sphere was overcome by an undertaking of Addis Ababa authorities to make a substantial use of sterling as reserve currency. In addition, as a preliminary step, a loan on silver was obtained from the United States on the base of the Lend-Lease Act of $11^{\text {th }}$ March $1941 .{ }^{6}$

With the above mentioned law of $29^{\text {th }}$ May 1945, which contextually repealed the previous Legal Tender Proclamation n. 32 of 1942, an Ethiopian monetary system was established on the decimal system and based on a currency denominated "the Ethiopian dollar" which was nominally in gold. In compliance with the precepts of Bretton Wood agreement concerning International Monetary Fund, an initial parity, establishing weight and fineness, was set, corresponding to 5.52 grains of fine gold and, consequently, to 40,25 U.S. cents. ${ }^{7}$

Monetary functions were attributed exclusively to the State Bank of Ethiopia upon Government delegation. Since the Bank was to continue to grant credit and make commercial loans, it was considered best to separate the two activities in laying definite plans by creating an Issue Department within the Bank's organization chart. Thus the task of issuing notes and coins was fully entrusted to this department of the Bank. ${ }^{8}$

To back the issue of bank-notes a monetary reserve known as "the Currency Fund" was to be set up, but the name was, in fact, improper and misleading since only issue of notes and not of metal token coinage was covered while the term "currency" encompasses both. The Fund was to be composed of not less than $75 \%$ gold, silver and foreign hard currencies (in bank balances or prime securities readily convertible) with the remaining in Ethiopian Treasury Bonds. The Issue Department was subject to direct supervision by the Ministry of Finance. The Ethiopian Ministry of Finance was also empowered to regulate procedures to be followed in exchange transactions as well as in the withdrawal of the other currencies circulating in the country.

This ministry had also the task to fix the exchange rates of circulating currencies with the new currency. In addition, the exchange rate was set at which the value of obligations contracted prior to July 1945 and pending financial transactions denominated in East African shillings at 23 July 1945 was to be converted into Ethiopian dollars. That rate was two shillings per Ethiopian dollar. With reference to values of obligations contracted prior to July 1945 and pending transactions denominated in Maria Theresa thalers, instead, an exchange rate was not fixed at this time and the task was left to the State Bank of Ethiopia. A legal exchange rate of parity for the Maria Theresa's thaler to the Ethiopian dollar was, however, established for the conversion into the new Ethiopian monetary unit of all values denominated in thalers mentioned in all legislative acts then in force.

Differing treatment of the two currencies in circulation in the country at the time of the reform had been foreseen and was clearly reflected in the expiry dates of their status as legal tender. The Maria Theresa's silver thaler was to have ceased to hold such a status when the law in question came into force. The State Bank of Ethiopia was to have handled the withdrawal from circulation of these

\footnotetext{
${ }^{5}$ See E.W. Luther, Ethiopia, p. 105

${ }^{6}$ See State Bank of Ethiopia, Economic Conditions and Market Trends, May 1955, p. 8.

${ }^{7}$ See Art 2 of Proclamation $N^{\circ} .76 / 1945$ and Art. of the Attachment A to this law. See also Z.A. Konczacki (1962)

${ }^{8}$ See Art. 3 of Proclamation $\mathrm{N}^{\circ}: 76 / 1945$ and Art. $\mathrm{N}^{\circ}$ : 1 and Art. $\mathrm{N}^{\circ} .2$ of the ordinances in Attachment A.
} 
full-bodied silver coins on the basis of a variable exchange rate to be established periodically taking in due account silver price trends. The East African shilling was, instead, to maintain its legal tender status for another half-year. Nonetheless, certain limits were placed on the circulation of this British colonial currency's fractional coins.

The law, additionally, established the denominations to be adopted for the new currency: the Ethiopian dollar. The task of specifying the features of the notes and coins was entrusted to the Ministry of Finance. The issue of $1,5,10$, 20, 50, 100 and 500 Ethiopian dollar bank-notes as well as the minting and issue of copper pieces corresponding to $1,5,10$ and 25 cents and a silver 50-cent piece were planned. ${ }^{9}$

Both the bank notes and coins were made in the United States and the shipment to Addis Ababa was done via Djibouti. With the introduction of the new currency, however, some problems arose with the 25 cents copper pieces. ${ }^{10}$

However, the forecasts of Ethiopian authorities turned out to be, as usual, excessively optimistic. The Maria Theresa's thaler continued, in fact, to circulate as a means of payment liked by the public and the State Bank of Ethiopia, given its very limited branch network, was definitely unable to carry out, as planned by the Ethiopian government, the replacement of the Austrian silver thalers. Furthermore, a large part of the population even totally ignored the monetary reform brought in by the Ethiopian authorities. But also the withdrawal of the East African shillings - which presented undoubtedly much less concern since this currency, used primarily by foreign businessmen and upper income groups, circulated mainly in the most important commercial centres - took much more time than had been foreseen by Addis Ababa authorities. The initial half-year transition period in which this currency was still to be considered legal tender had thus to be reluctantly extended. However, a non-extendible expiry date for the circulation of East African shilling was set at $23^{\text {rd }}$ May 1946. ${ }^{11}$

Following the definitive disappearance of the East African shilling, every possible course of action was taken by Ethiopian authorities to complete the withdrawal from circulation of the Maria Theresa's silver thalers. This was a goal which two attempts at monetary reforms had already failed to achieve in the past. The first had been promoted by Menelik II at the start of the century, the second by Haile Sellassie himself in the mid-thirties. Not even the Italian colonial administration, with the advantage of a large banking branch system spread throughout the Ethiopian territory, had succeeded in this action (Mauri 1967).

A first law issued on $30^{\text {th }}$ November 1946 (Proclamation $N^{\circ} .81$ ) forbade not only payments and trade but also hoarding of Maria Theresa's thalers and contemplate heavy fines on violators. It is interesting to point out that prohibition of hoarding was not easily understandable in a country where a large use of the Austrian silver coins was made in jewels production (Pankhurst 1965; Mauri 2004). The law was to take effect on different dates in the various regions of the country.

\footnotetext{
${ }^{9}$ According to art. 6 "the currency notes issued by the State Bank shall be legal tender in Ethiopia for the payment of any amount" and "coins issued under this Proclamation shall be legal tender for any amount in the case of silver coins and not exceeding ten dollars in the case of base metal coin".

${ }^{10}$ In fact the silver piece of 50 cents was equal in dimension to the 25 cents copper piece and counterfeiters dipped the copper quarters in a nikel solution passing them off as half dollar pieces (Deguefe 2006).

${ }^{11}$ See Legal Notice 90/1945 in Negarit Gazeta of $30^{\text {th }}$ November 1945.
} 
The results, however, fell so far below expectations, that a second law was enacted few months later which extended the deadlines previously set. ${ }^{12}$ But the Maria Theresa's thaler continued to circulate even after the expiry date set by this second law. Thus, with Proclamation $\mathrm{N}^{\circ} .105$ Negarit Gazeta of $27^{\text {th }}$ August 1949) it was enjoined in peremptory terms that these silver coins had to be delivered to the State Bank of Ethiopia and reasserted the absolute ban on negotiating them for any other purpose. The law cited contemplated a fine of up to 5,000 Ethiopian dollars and imprisonment up to five years for violators.

At the time when Eritrea, following a United Nations resolution, was federated with Ethiopia, the problem arose in introducing Ethiopian currency into this territory as legal tender in the place of East African shillings circulating under British Administration (Rena 2007). Proclamation $N^{\circ} .127$ of $25^{\text {th }}$ September 1952 was enacted to this end. It extended the Ethiopian monetary system to the incorporated territory and prescribed that the value of all pending financial transactions be converted into the national currency at the rate of 2.86 East African shillings per Ethiopian dollar.

The official exchange rate was considered slightly disadvantageous by the Eritrean businessmen, since in the past the Ethiopian dollar had been valued and traded at about 2.50 shillings on the Asmara free market. However, the introduction of Ethiopian currency into Eritrea did not create serious problems, since Maria Theresa's silver thaler had for some time held only a marginal position among the currencies in circulation (Caselli \& Mauri 1986).

\section{The Development of the State Bank of Ethiopia}

The State Bank of Ethiopia, established, as we have seen in Section 2, by imperial proclamation on August $26^{\text {th }}, 1942$, came into being as a simple commercial bank in the form of a limited company with capital fully vested by the State. The Board of Directors had to consist of not less tan five or more of seven Directors appointed by the Imperial government and President and Governor of the Bank were to be appointed among the Directors. The State Bank of Ethiopia began operations in April of 1943, under a Canadian governor, ${ }^{13}$ at the Addis Ababa headquarters. The management of the Bank was in the hands of foreigners. The staff consisted of a small workforce of around 40 employees of varied nationalities comprising Armenian, Austrian, Greek, Hungarian, Indian, besides, of course, Ethiopian (Deguefe 2006).

Two branch offices were soon opened in the same year, the first in May at Dessye and the second in August at Diredawa. In April 1944 the Jima branch started operations and other branch openings followed throughout the country's provinces.

At the time operations began, the Bank was engaged in the collecting of deposits in current accounts, in mail and telegraphic transfers and in the granting

\footnotetext{
12 See Proclamation N ${ }^{\circ} .99$, in Negarit Gazeta of 29th April 1947.

13 The first governor was, in fact, Mr. Charles .S. Collier, who in the past had served Vice Chairman in the Board and had been the last Governor of the Bank of Ethiopia, the financial institution liquidated by Italian Colonial Administration after the conquest of Ethiopia in 1936 (Mauri 1967). After the sudden death in a car accident of Mr. Collier an American, Mr. Blowers from First National City Bank ,got his job (Deguefe 2006)..
} 
of credit to private parties in the form of mortgage loans, advances on merchandise and personal loans, the latter being provided according to the Ethiopian custom. Overdraft facilities were offered to a number of firms (Luther 1958). The Bank's functions also included the management of the national debt and foreign exchange reserves.

The main activity in this respect was represented by currency exchange transactions and in operations as fiscal Agent and Counsellor of the Imperial government in credit operations and in the issue and management of public loans. The Bank had also the duty to take charge of services to the Treasury.

A decisive turn of events in the Bank's history came with the monetary and banking reform of May $29^{\text {th }}, 1945$. By this law the State Bank of Ehiopia also became a bank of issue. Hence began the evolutionary process which, corresponding to the enactment of a series of monetary, banking and foreign exchange laws, was to transform this financial institution into a genuine central bank. A further sep in this direction was later taken with the law of June $28^{\text {th }}$, 1948, which gave the Bank a monopoly on foreign exchange operations and with other legislative acts entrusting it with a relevant role in the regulation of currency.

The above mentioned legislative measures brought about administrative and structural innovations as well. The organizational structure had been, in fact, modified first in 1945 with the creation of an Issue Department. The immediate effect of this decision was the establishment of a second department: the Banking Department, devoted to ordinary banking activity. These two departments prepared separate balance-sheets which then were to be consolidated into an overall balance-sheet of the Bank.

In 1949, when the State Bank of Ethiopia assumed specific responsibility for foreign currency regulation, a Foreign Exchange Office, headed by the Exchange Controller was set up within the Issue Department of the Bank. This office also was charged with the task of writing regulations, since the Bank had been empowered to regulate all foreign exchange transactions. Exporters were therefore obliged to hand over $100 \%$ of foreign currencies obtained abroad to the State Bank of Ethiopia, while the Bank itself rationed foreign currencies to importers, subjecting every single request to its scrutiny. Correspondent accounts were opened with a number of financial institutions abroad in eighteen countries (Luther 1958).

The powers of the State Bank of Ethiopia in monetary management were increased by a law issued on March $30^{\text {th }}, 1950$. Another significant step in the evolutionary process leading to the creation of a central bank had been taken with the Proclamation $\mathrm{N}^{\circ} .110$ of November $30^{\text {th }}, 1949$, which changed the name, the features and the rules of management of the Agricultural Bank of Ethiopia. In fact, Article 4 of this law assigned to the State Bank of Ethiopia the task of supervising operations of this institution. The Agricultural and Commercial Bank of Ethiopia (the new name) was obliged to keep required liquidity reserves (to back the deposits collected) at the State Bank of Ethiopia.

After the completion of British administration, in 1952, Eritrea had been federated with Ethiopia and, consequently the State Bank of Ethiopia had taken over the two Eritrean branches of the Barklays Bank operating respectively in Asmara and in Massawa (Mauri 1967; Rena 2007).

The effects of the federation of Eritrea with Ethiopia were even more relevant in this regard. The Italian bank branches (Banco di Napoli and Banco di Roma) operating in the federated territory were placed under supervision of the 
State Bank of Ethiopia, which became also a banker's bank for two of these. The monopoly in foreign currency transactions as well as the high commission rate charged by the State Bank of Ethiopia on these transactions effectively discouraged foreign bank branches from turning to their mother-institutions abroad for re-financing operations. Actually, it was definitely much more helpful and cheaper to make use of the rediscount facilities offered by the Ethiopian central bank. As a result the Bank had a broad and general authority over the issuance and circulation of money, over foreign exchange and in supervising financial intermediaries.

From the outset of its operations, the State Bank of Ethiopia took upon itself the task of setting up a network of branches throughout out the country. The opening of new branches served first to spread the use of currency and to gain familiarity of the people with banking services. In this way the infrastructure created could play a relevant role in promoting economic development in the various provinces of the country. This policy of opening new branches had a long term target and was followed even when short term effects on profitability were uncertain. According to Luther (1958), during the fifties, whilst the branches of Asmara and Diredawa were highly profitable, some other branches, especially those opened in the most remote areas of the country, were definitely not viable. ${ }^{14}$ However, the policy followed by the Bank was to maintain non profitable branches opened in order to make people more acquainted with the national currency and banking facilities. In fact, the State Bank of Ethiopia enjoyed a monopolistic position in the country (with the exception of Eritrea) and could earn enough money to face the increasing costs brought about by the expansion of the branch offices network. These additional costs were in essence a burden distributed evenly among the whole customers' community in the form of higher prices for banking services and of a wider spread between borrowing and lending rates.

At the end of 1954, the State Bank of Ethiopia had sixteen branch offices. The headquarters in Addis Ababa, the "Mercato" branch at the new market of the city and other fourteen branches, one of which located abroad (the transit office in Djibouti). Domestic branch offices had been opened in Asmara, Assab, Dessye, Diredawa, Gambela, Jijiga, Jimma, Gonder, Lekemti, Massawa, Nazareth (Adama), Teseney and Wardere. In most cases the Bank took over for its branch offices premises that had belonged to Italian banks such as Banca d'Italia or Banco di Roma (Deguefe 2006).

The extension of the branch network and the increased work load at the Bank Head office necessitated a considerable increase in staff. By the end of 1954 employees numbered 574 and two years later this number had risen to over 600 . At the same tame the State Bank of Ethiopia had a large network of foreign correspondents, including thirty-three banks in seventeen countries. In 1958 two new branches were added to the net: the first in Dembi Dolo, in the midst of a rich coffee growing agricultural area, and the second abroad, in Khartoum.

The branch of Khartoum, opened in April 1958, according to the Sudanese legislation had assigned a seed capital of 300,000 Sudanese pounds and its principal goal was to promote and assist Ethiopian trade with the bordering country. The inauguration ceremony of the State Bank of Ethiopia branch was attended by the Minister of Finance of Sudan and by the Ethiopian Ambassador (Deguefe 2006). The Karthoum branch did not follow, however, the model of the

${ }^{14}$ According to Luther (1958 p. 100) "ten of the sixteen branches operated at loss in 1954 and 1955, and about the same number in 1956 and 1957." 
Djibouti branch and began to operate as an autonomous financial institution in the Sudanese credit market. Most of the clients were Sudanese and Indian traders; among depositors there were many Eritrean residents, but the most profitable deposit account at the branch was definitely that of the Saudi Arabian Embassy in Sudan (Deguefe 2006).

The increased size of business carried out by the Bank required a larger capital funds. The capital of the State Bank of Ethiopia had been raised, therefore, to 10 million Ethiopian dollars. ${ }^{15}$

In November 1959 an important event in the Bank's history took place: Menasse Lemma assumed the office of Governor. It was the first time an Ethiopian citizen had been called upon to hold this post in the State Bank of Ethiopia as well as in previous financial institutions involved in issuing currency such as the Bank of Abyssinia and the Bank of Ethiopia. But training and placement of Ethiopian personnel among Bank's senior and management posts at all levels was going on since few years. In the early nineteen-sixties the State Bank of Ethiopia had about 800 employees distributed between the head office and the twenty-one branches (Deguefe 2006). Besides Addis Ababa, the cities of Asmara, Assab, Bahir Dar, Dembi Dolo, Dessye, Diredawa, Gambela, Jijiga, Jima, Gonder, Gore, Harar, Lekemti, Mekele, Massawa, Nazareth (Adama), Shashemene and Teseney had, at least, one branch office each.

The rapid growth of the State Bank of Ethiopia was due to the widening of the area of the country covered by its operations thanks also to the extension of banking facilities to the various provinces (Luther 1958). The growth was also the consequence of the gradual increase of money supply and of the deepening of the activity of the Bank following the development of the economy and the expansion of international trade. The increase in size of the Bank is even better illustrated by the series of data shown in Table 1 .

insert Table 1 about here

The second column totals indicates "assets" at the end of each financial year during the decade 1953-1963. Actually, these "assets" correspond solely to those of the Banking Department, since the total assets of the Issue Department (equal to the consistency of the "Currency Fund", the backing against which the State Bank of Ethiopia issued notes) automatically corresponded to the sum total of bank-notes in circulation. The increase, taking into account the stability of the Ethiopian currency's purchasing power, is significant. The slight sag in the 19581959 two-year period can be blamed on the fall in the international business cycle.

An even more vigorous trend in growth can be seen in the other series of data concerning the capital and components of the profit and loss statement. It must be underlined that more than half of total expenditure was accounted for personnel costs. The commissions from foreign exchange transactions accounted for approximately $50 \%$ of total proceeds, while interests earned contributed only

15 The capital of the State Bank of Ethiopia was one million Ethiopian dollars in 1945; it was increased by 500,000 Ethiopian dollars in 1946 and the same amount in 1947. In 1953 the capital was raised to five million and then doubled in 1957. 
one third. Investments in foreign securities earned about half of interests during the first years of the 50s. For the most, these were bonds in U.S. dollars issued by the International Bank for Reconstruction and Development (Luther 1958).

\subsection{The Monetary Functions of the State Bank of Ethiopia}

The monetary reform undertaken by Ethiopian authorities and brought in by the law of $29^{\text {th }}$ May 1945 had granted to the State Bank of Ethiopia the privilege of note issue. This institution had the monopoly of issuing bank-notes and token coins. At the same time the State Bank of Ethiopia was the only bank in the country authorized to collect checking account deposits and therefore it was in a position to control the total official components of money supply. However, in fact, the situation at the moment in which the new regulations came into force presented problems that were not easy to face and solve and the Bank could do little in the way of finding suitable answers.

In the first place other currencies, especially the East African shillings and the Maria Theresa's silver thalers, had to be withdrawn from circulation and replaced with the new national currency. Secondly, the monetary area of the Ethiopian economy, according to general views of development economists (Drake 1980), needed to be enlarged in order to speed up the economic development in the whole country.

The populace's deeply-rooted preference for the Austrian made silver coin made it advisable to avoid total elimination of silver in the new minting. A recourse was thus necessary to the above mentioned U.S. silver loan, which made slightly more than 168,739 kilogrammes of silver available. Repayment of the loan, again in silver, was to coincide with the withdrawal from circulation of the Maria Theresa's silver thalers. ${ }^{16}$ The metal was used to mint in silver the Ethiopian dollar 50 cent, as token coins; a decision, however, was made not to strike one-dollar pieces. Ethiopian silver coins in circulation accounted for about two thirds of overall face value of token coins during the first decade.

insert Table 2 about here

Table 2 highlights the slow, but progressive, replacement process of foreign currency by domestic currency. Figures of the total amount in value of issues at the end of each year are given, subdivided into bank-notes and coins. However, it should be noted that the overall figures listed in the fourth column do not refer to the actual circulation of notes and coins, since they are gross of cash in hand at the Banking Department of the State Bank of Ethiopia and other banks. The final column indicates the percentage of bank-notes per issue and shows the public's preference for one of the two types of money. In fact, this ratio between coins and bank-notes to a certain extent reflects the needs of the market.

${ }^{16}$ Total repayment of the U.S. silver loan of $\$ 9.6$ million took place in 1958 , but was entered in the books the following year. See State Bank of Ethiopia, Economic Conditions and Market Trends, February 1960. 
The figures in Table 2 show that during the first two years there was a considerable issue of currency, characterized by a high percentage of bank-notes. The phenomenon may be explained by recalling the withdrawal of East African shillings, which took place during this first phase. Since the note is a means of payment commonly used by upper-income brackets and in urban areas, it is easy to understand why it accounted for about three-quarters of total issues. In the following years growth rates slowed down owing to the gradual withdrawal process of Maria Theresa's thalers. The reason was that those holdings these silver coins appertained to the low-income brackets and resided in more backward areas of the country. Therefore it was necessary to increase the share of token coinage, which, being metal, was more readily accepted for both settlement and hoarding purposes.

A different phenomenon appeared following the annexation of Eritrea. Here, the withdrawal of the East African shillings led to an expansion of issue and to an increase of the percentage of bank-notes. This percentage increase steamed from the fact that many Eritreans had for a long time been accustomed to make use of paper money (Mauri 1967). Coming back to the total figures of Ethiopia it is possible to see in the Table 2 that in the following years there was an increase both of issues of domestic currency and of the percentage of notes within total currency.

The Currency Fund was initially mainly composed of East African shillings, which were at first converted into sterling and deposited with English banks in London. Later, these funds were invested in British gilt edged securities so as to make them sufficient interest bearing. Even Maria Theresa's thalers withdrawn from circulation went to enlarge silver reserves whilst gold ingot reserves were increased mainly by domestic gold mining production. Later, hard currencies reserves grew rapidly thanks to a series of surpluses resulted in the country's balance of payments (foreign exchange proceeds from merchandise exports, mainly coffee, ${ }^{17}$ the berries, and sale overseas of newly mined gold).

At the end of 1946, the Currency Fund consisted of 5\% metal reserves, 93\% of foreign currency reserves and 2\% Ethiopian Treasury Bonds (Luther 1958). Thus, in percentage terms, metal and foreign currency, or readily convertible prime securities, reserves for the backing of issues exceeded significantly the legal minimum of $75 \%$, a ratio which - we should underline - was criticized as excessively high from the start.

This policy decided by Ethiopian monetary authorities had doubtless contributed to gain confidence to the Ethiopian currency both at home and abroad among prominent international financial circles. But it demanded also to keep idle capitals in the form of precious metal and of foreign exchange reserves, an absurd sacrifice, which was particularly onerous for an economically backward country in need of imports of capital goods (Fry, Goodhart \& Almeida). An event of relevant international dimensions was hence necessary to persuade the lawgiver to

\footnotetext{
${ }^{17}$ According to Forbes Munro (1976, p. 189), "in Ethiopia ...the Italian occupation left a legacy of improved roads which permitted the exporting of agricultural commodities from the highlands. Coffee exports, rising in value from $\$ 8,900,000$ in 1949 to $\$ 40,000,000$ in 1953 , quickly surpassed those of cereals, oilseeds and hides. The greater part of the output, however was gathered from natural coffee forests in the western and south-western areas of the country which, nominally under government ownership, passed into the hands of members of Ethiopia's landowning aristocracy. A small class of landlords, who brought in labour from other areas to pick the berries were the principal instigators and beneficiaries of Ethiopia's post-war coffee boom"
} 
modify Article 4 of the monetary and banking reform law. That world-wide event was the devaluation of the British sterling (Caselli \& Mauri 1986).

The amount of Ethiopian hard currencies reserves witnessed a considerable drop as a result of the British authorities' unexpected decision. Since possible devaluation of the Ethiopian dollar had been categorically excluded, it become necessary, although unwillingly by Addis Ababa authorities, to amend the Currency and Legal Tender Proclamation of 1945. It was reduced the minimum percentage of backing of issues from $75 \%$ to $30 \%$ with the Law n. 112 of $30^{\text {th }}$ March 1950. This legislative act, as stated by Luther (1958), had the important effect of releasing more than seventeen million dollars in foreign currency to the advantage of imports for the economy of the country. At the Art. 6 of this act it was added that the Government and its subsidiaries had not to become indebted to the State Bank of Ethiopia in an amount exceeding 3 million of Ethiopian dollars on direct obligations and 2 million on indirect obligations.

insert Table 3 about here

At the end of 1955, the Currency Fund was made up as follows: $20 \%$ metal reserves, 31\% hard currencies reserve, $49 \%$ Ethiopian Treasury Bonds. Thus the policy of maintaining a constant margin for potential expansion of bank-note circulation was continued as shown by Table 3 . This table illustrates the changes in the composition of the "Currency Fund" occurred in the period $31{ }^{\text {st }}$ December $1956-31^{\text {st }}$ December 1963. The unforeseen decrease in silver reserves in 1959 was caused by the repayment of the silver loan to the U.S. Treasury. ${ }^{18}$ The drops in gold reserves in the years 1962 and 1963, on the other hand, were brought about by shipments of this metal to Europe to be refined and later consigned to the International Monetary Fund in order to increase Ethiopia's membership.

Let us now consider a third monetary component, i.e. deposit money, in order to examine trends in the overall volume of country's stock of money. It must be specified in this regard that payments by checks or giro were usually made only by a small minority of businessmen even in the post-war period. Yet, starting with mid-fifties, following also the annexation of Eritrea, a trend of growth in the use of this type of money became evident. The error must be avoided, however, of considering the ratio between currency in circulation (coins and bank-notes) and the balance of demand deposits (excluding interbank current accounts) as a reliable indicator of the use for settlement purposes of each of these two kinds of money; each of them has, in fact, a different circulation velocity.

It should be considered that the check, even today, is practically unknown in some areas of Ethiopia, but at that time it was unknown in most of the country. Luther (1958) asserts, to this regard, that customs authorities in Assab and Massawa repeatedly refused to accept checks certified by the State Bank of Ethiopia. This author comments that in the 1950s the use of checks was an exception, even in the capital city of Addis Ababa. Thus, in practice, according to Luther (1958), merchants frequently opened current accounts at the Bank not so

${ }^{18}$ See note 12. 
much to make use of them for payments, but rather for safe-custody, transfer and other services, but settlements were made mostly in cash.

insert Table 4 about here

Let us examine, in Table 4, the stock of Money in Ethiopia in terms of the aggregate M1 at the end of each year during the 1948-1963 period. It is worth at this point to remind that as far as the 1945-1947 three-year period is concerned, only the overall amount of deposits in current account, including the balance of Treasury current account deposits, is available. Figures on money supply, therefore, are not comparable with those that follow. ${ }^{19}$ The same table indicates the data used to make the calculation.

In the table's second column is indicated cash on hand in the State Bank of Ethiopia's Banking Department as at December $31^{\text {st }}$ of each year. The difference between the values given in the third column of Table 2 and those now given shows the actual circulation of bank-notes and coins. The fourth column reports the amount of deposits in personal current accounts at State Bank of Ethiopia and the fifth column performs a corrective and integrative function starting from the date Eritrea was annexed. It shows the overall amount of current account deposits at the Italian banks' branches in Eritrea, net of the corresponding stock of cash on hand. The sixth column of the table reports data on the stock of money. The last two columns record, respectively, the percentage weight of bank-notes and coins, and that of deposit money in the makeup of the stock of money.

In fifteen years the overall volume of money in Ethiopia witnessed a $236 \%$ increase without, however, causing and inflationary spiral. This signifies that growth was compensated by the rise in gross national product and above all by the expansion of the domestic economy's monetary area. As far as the qualitative makeup of the stock of money is concerned, the share of deposit money increased from $22.7 \%$ to $29.4 \%$. However, the trend was not constant through time, as can be seen from the counteracting fluctuations in the two series of data just examined.

Unquestionably, the pace of expansion of money supply and the long-trend to increase the weight of deposit money are clear indicators of the progress made by Ethiopian economy during the whole period under examination. However, the amount of money supply showed frequent ups and downs. In only one case there was a drop in absolute value, whilst in all others it was merely a question of wide fluctuations in the annual growth rate. It must be recalled in this regard that, especially at the beginning of the period under consideration, the "foreign" channel represented the main variation factor in the stock of money.

The elimination of Maria Theresa silver thalers from circulation and the introduction of Ethiopian currency had only in part attenuated the rigidity of the preceding monetary circulation. The almost complete covering of the new issues with hard currency and metal reserves, as well as the limited diffusion of deposit money, had created a strict correlation between figures of the country's balance of

\footnotetext{
19 At the end of 1945 the money supply of Ethiopia, calculated using the criterion put forth, corresponded to 43.3 million Ethiopian dollars; a year later a 36 million dollar increase had been recorded. Finally, on December $31^{\text {st }} 1947$, the overall money supply totalled 84.2 million Ethiopian dollars.
} 
payments and that of money supply. The increase in money supply equalized the surplus of international receipts over international payments. The balance of payments data in turn reflected to a decisive extent the value of coffee exports. ${ }^{20}$

\subsection{The Financial Intermediation Functions of the State Bank of Ethiopia}

The State Bank of Ethiopia began collecting deposits and making loans as early as the spring of 1943. Since the State Bank of Ethiopia among other activities, acted as banker of government, the Bank's most important client was the Ethiopian Treasury, which appeared in the first phase both among the debtors and creditors in current accounts. Treasury deposits had to be managed not only with an eye to the actual financial needs of the government but also with an eye to monetary policy. Furthermore it were not to be neglected also the possible effects of government transactions on the geographical distribution of the money supply among the various provinces of the country.

The State Bank of Ethiopia in the beginning of its activity also collected deposits from private parties opening current accounts in Maria Theresa thalers as well as in East African shillings. However, since the 1945 monetary and banking reform (Currency and Le gal Tender Proclamation n. 76 of 1945), all accounts had to be converted into Ethiopian dollars. In particular, according to the paragraph (d) of the Art. 4 of the enclosed Schedule C (transition period) of the law, the Bank was interdicted in accepting further deposits in Maria Theresa silver thalers starting July $23^{\text {rd }} 1945$.

The second objective pursued by the State Bank of Ethiopia, after that of replacing currency in circulation, as sted before, was to collect deposits. Deposits in current account were non-interest-bearing, but offered depositors valuable services. An initial minimum deposit of 250 Ethiopian dollars was required, but no minimum balance requirement existed once accounts were opened. In 1946 the Bank decided to set up a programme of deposit collection aimed at promoting and mobilizing household savings.

The savings deposits category was first designed to met the needs of small savers. Only five Ethiopian dollars were needed in order to open a savings account and subsequent deposits were to be of not less of one dollar each time. In accordance with the aims pursued, certain conditions were laid down, some of which created stiff limits: passbook had to be personal and each saver could have no more than one account in his name; the amount of a single account was not to exceed 5,000 Ethiopian dollars; not more than two withdrawals per month were permitted, neither of which was to exceed $25 \%$ of the account balance; accounts could be closed with a one-month notice. On the other hand no limits were placed on the frequency and maximum amount of each deposit. Depositors benefited of $4 \%$ interest rate calculated on the minimum monthly balance of the account with twice-yearly interest accrual, but if the balance dropped below 25 dollars the account cease to bear interest.

Fixed-maturity deposits, however, had no limitations other than withdrawal time set up at the beginning. Deposits with six-months term earned a $2 \%$ annual rate, while one-year term deposits earned 3.5\%. It may be noted that interest rates offered by the Bank to savers were very low when compared to usual conditions

${ }^{20}$ Coffee exports during the period under consideration (except 1959) always accounted for more than half of overall Ethiopian exports in terms of international receipts 
of the Ethiopian credit market. Evidently the State Bank of Ethiopia did not trust the reward effect as an incentive to promote savings mobilization through deposits, but rather considered more important the safety factor offered to customers. However, the Bank changed to a certain extent attitude later and, consequently, interest rates were raised and operational limits on the various technical forms of deposits were relaxed.

In 1958 the interest rate earned on savings deposits was raised one-half percent. On the other hand, in 1961 the maximum limit on the balance of each savings deposit account was abolished and, at the same time, interest rates were diversified. In fact, a $4.5 \%$ rate was to be paid on deposit accounts not exceeding 10,000 Ethiopian dollars. If the balance exceeded this amount, the excess balance earned only $2.5 \%$. Again, in 1961, time deposits regulations were changed. First of all, a new financial product for collecting deposits was introduced. A one month's notice was combined with a rate of $2.5 \%$. In addition, interest on sixmonth fixed-term deposits was raised to $3 \%$ per annum. All these rewards on savings deposits were tax free (Batha, Gryziewicz \& Tickeher 1965).

insert Table n. 5 about here

The second column of Table n. 5 witnesses the considerable increase in the Bank's deposits during the period the end of 1945 to the end of 1956. These figures, however, include also the Treasury current account and deposits by Public Agencies as well. Table n. 6 and Table n. 7 turn out to be more revealing. The former illustrates the growth of the total deposit balances with the State Bank of Ethiopia during the period $31^{\text {st }}$ December 1957- $31^{\text {st }}$ December 1963, as well as changes in the make up of such deposits. On the other hand, Table n. 7 allow us to better observe the trends of the different categories of deposits.

insert Table n. 6 and Table n. 7 about here

The analysis of the data recorded in the latter two tables gives the opportunity for drawing some conclusions. First, the decline of public deposits is witnessed in terms of both absolute figure and percentage. These deposits accounted for $57.7 \%$ at the end of 1957 , but six years later, after a decline of approximately $25 \%$, their share had shrunk to $39.7 \%$. The fact is not important in itself except that it makes the overall growth of deposits less apparent. The amount of public deposits was often swollen after the Sate Bank of Ethiopia had granted non-interest-bearing loans to the Ethiopian Treasury. The Treasury's promissory notes acquired by the Bank in the transactions were added to the Currency Fund, thus freeing foreign currency reserves, which, transferred to the Banking Department, allowed to expand lending tied to foreign trade.

Time deposits show a steady trend in growth accompanied by a slight decrease in percentage. On the other hand, current account deposits and savings deposits show a remarkable growth rate. The former witnessed a $42 \%$ rise, in percentage from $27 \%$ to $34.8 \%$. The increase in savings deposits was really impressive, their total amount, during the six years period, more than tripled, moving up in percentage from $3.9 \%$ to $14.6 \%$ of the overall total. 
Without doubt, various factors contributed to the expansion in number and in total amount of current account deposits. Among these we can underline the extension of the Bank's branch network, the widening of Ethiopian economy's monetary area and the growth of the economy itself. The spread of the use of deposit money as a means of payments through checks and transfers represented, perhaps, a less important contribution.

The factors above cited also influenced the growth of savings deposits in number as well as in total amount. More than an increase in saving propensity it was a gradual change in the habits which spurred the growth. As a consequence, a variation occurred in the composition of the wealth portfolios of households, where tangible assets were replaced by financial instruments. The reduction of hoarding came out mainly in urban areas and among the emerging middle class (traders, employees, shop-owners) and was brought about by the presence of bank branches in all urban centres. The limited participation of the lower-income groups is proved by the fact that the sum of 100,000 Ethiopian dollars - the ceiling set started in 1961 - was considered an enviable wealth at that time in the country.

The uneven trend in time deposits is clearly tied to the peculiar nature of these deposits in Ethiopia. In fact, these deposits were most often temporarily liquid assets, deriving at times from disinvestments, kept for a certain period at the Bank waiting for profitable new investment opportunities. Thus, a change in conditions offered by the Bank or in the outlook of the market sufficed to bring about sudden shifts of funds, with consequent notable variations in the total amount of these deposits. There is little doubt that the adjustments decided by the State Bank of Ethiopia in 1961 on interest rates and on terms of time deposits contributed to a reversal of trend. The increasingly wider range of opportunities for direct investments opened up by economic progress and industrial development must certainly have had a negative impact on the growth trend of time deposits.

Examining again Table n. 5 and comparing investment and deposit figures brings to light an uneven trend in the former in contrast with the steady rise of the latter. The percentage ratio between the data of the two columns show remarkable instability, fluctuating between the maximum reached at the end of 1949 (investments $=83.2 \%$ of deposits) and a minimum in 1954, when this ratio had fallen to $18.8 \%$. Furthermore these percentages are to be considered low when compared with the average percentage of advanced banking systems.

This situation came out first of all because a large share of credit provided by the State Bank of Ethiopia was channelled towards financing the Ethiopian Treasury, whose indebtedness was not always determined by actual need and had sharp fluctuations over time. Secondly, it can be observed that the Bank, or, more properly, his Banking Department, kept large idle funds even though it was not subject to legal reserve requirements.

The high percentage of liquidity depended above all on the need to keep adequate cash in each in each of the branch offices, since these offices were spread in a vast territory where communication was often slow and sometimes extremely difficult, mainly during certain seasons. Until the mid-fifties many branches were above all centres were coin and notes were distributed and changed; they, in short, were mainly used for transfer, collection and payment services.

From the outset, while all the Bank's branches were allowed to collect deposits in current account and in almost all to collect savings as well as time 
deposits, only the Dessye, Diredawa branches carried out some appreciable lending operations. ${ }^{21}$ On the other hand the branches opened in Eritrea in 1952 began immediately to be engaged in credit transactions.

A number of branch offices kept exceedingly high cash reserves because of the seasonal nature of their deposits. With the exception of most important branches as Asmara and Diredawa, branch holdings of cash usually represented over $90 \%$ of total assets of each branch compared with less than $25 \%$ of the Addis Ababa head office (Luther 1958).

Some branches operated mainly as collecting counters, funds taken in locally were siphoned off to the Addis Ababa central office. In fact Addis Ababa headquarters centralized most of the loan activity of the Bank. The largest share of lending was directed towards the Ethiopian Treasury and State Agencies. The seasonal ebb and flow of funds between head office and branches was fairly common. However it must be pointed out that the limited amount of loans granted by most of the branch offices also depended on very cautious criteria followed in the lending policy of the State Bank of Ethiopia. Furthermore branch personnel were not adequately trained and not only lacked of initiative in approaching customers and potential customers, but often turned out business opportunities in order to avoid risks which they were unable to assess adequately.

In the following period of the life of the State Bank of Ethiopia a greater number of requests for loans, a change in the lending policy and an improvement of the quality of personnel due also training programs made possible a substantial increase of lending. However, in June 1963, cash on hand still exceed $90 \%$ of total assets in the Gambela, Gondar and Gore branches.

Initially the credit to private parties by the Bank was granted principally on the form of mortgage loans, personally secured loans and advances on merchandise. The Bank was not particularly interested in the final destination of the funds loaned and the transactions were classified exclusively on the basis of technical features, particularly on the nature of the security offered. Mortgage secured transactions accounted for the majority of the private sector loans: next in importance were advances on merchandise and personal secured loans.

Mortgage loans had a minimum one-year, maximum six-year duration and were repaid in instalments. The annual interest rate charged on the outstanding loan was $8 \%$. Advances were often secured by export commodities, their duration did not generally exceed three months and the annual rate charged was $7 \%$. In all the transaction backed by collateral security the amount of the loan could not exceed half of the appraised value of the security (merchandise or real estate).

In the traditional Ethiopian loans, mostly addressed to consumption, a guarantor was required and a $9 \%$ annual rate was charged. However, there was a twofold limitation: their duration was not to be more than one year and the amount could not exceed 25,000 Ethiopian dollars. Discount transactions carried out the same interest rate. Credit was rarely granted on current accounts through overdraft facilities and limited to extremely trustworthy clients at a annual interest rate of $7 \%$. Later on, new types of loans were developed and an effort was made to discover the actual destination of loaned funds in order to imple ment policies of credit rationing and interest rates diversification with the aim to promote economic and social development of the country. It may be added that the expansion of credit granted to the private sector and the reduction of the

${ }^{21}$ State Bank of Ethiopia, Economic Conditions and Market Trends, November 1960. 
percentage of idle cash reserves in branch offices allowed interest rates on loans to be substantially lowered.

Starting in 1957 credit transactions were classified in the following way:
a) credit for building
b) other loans guaranteed by mortgage security
c) personal loans
d) commerce credit
e) advances on merchandise
f) export financing
g) current account facilities

The following year advances on securities were introduced. As may be easily noted, this classification was to some extent heterogeneous, since it was based differently on technical features of the loans or on the destination of loaned funds. The pricing system for loans in force in 1961contemplated a 7\% interest rate for the most of transactions. Export financing operations and advances on merchandise for export enjoyed, however, a reduction to $6 \%$ annual rate, provided their term did not exceed one quarter; personal consumer loans and the discount of trade bills were, instead, subject to an increase of the annual rate to $8 \%$.

\section{Insert Table n. 8 and Table n. 9 about here}

Table n. 8 and Table n. 9 allow to observe the overall trends as well as the trend by each class of investments, loans and securities, by the State Bank of Ethiopia during the period end-1957 to end-1963. In these two tables only credits granted to private parties and investment in stock securities appear. The growth in credit on current accounts is considerable. At he end of 1957 accounted for $22.3 \%$ of overall investments, but six years later the percentage figure had increased to $42.6 \%$. This phenomenon must be linked to the birth of a number of important industrial concerns as well as to the wider use of deposit money during this period.

Much less relevant was the growth of credit for building, given that mortgage loans had already strongly developed. It must also be mentioned that in 1959 restrictive measures had been adopted to slow down real estate speculation, which was pushing up construction of buildings and apartment house prices, mainly in Addis Ababa and affected dangerously foreign trade balance. The weight of these loans thus dropped from $28.3 \%$ to $13.2 \%$. For the same reason personal loans did not rise even in terms of absolute value and their weight dropped from $5.6 \%$ to $1.4 \%$. Export credit, on the other hand, developed autonomously following the trends in exports of agricultural products, mainly coffee.

Advances on securities began to be granted in 1958. The decision to develop this new type of loan was adopted in order to favour the placing of shares issued by a number of industrial concerns and public utilities companies. Again with the aim of promoting economic development and the industrialization process, investments were made in securities. The considerable increase in the size of portfolio of securities, and particularly of the component designated as dealing securities must be also linked to the Bank's efforts to stimulate the creation of a stock exchange (the Share Dealing Group) in Addis Ababa. The same objectives 
in promoting economic advancement were pursued directly by the Treasury through the development account set up at the State Bank of Ethiopia (Mauri 1967).

Finally, if we consider the overall trend of the Bank's investment in the private sector during the period under examination, we shall notice an even faster growth rate than that in deposits of the same sector. In accordance with this management orientation, reductions followed both in the reserve ratio and in the weight of funds going to the public sector. Thus, the State Bank of Ethiopia was concentrating efforts in developing entrepreneurship and firm investments in the private sector.

\section{Summary and Conclusions}

At a distance of approximately twenty years from the start-up of State Bank operations the Ethiopian credit system included - in addition to the Bank - three foreign bank branch offices and three non-banking financial intermediaries. In the commercial banking sector the Banque de l'Indochine, the Banco di Napoli and the Banco di Roma operated alongside the State Bank's Banking Department. The French bank had only one sub-office, located in Addis Ababa, which was not authorized to collect deposits; thus it served above all to acquire business for its Djibouti branch on which it depended and to maintain contacts with Ethiopian exporters.

Only two of the four Italian banks had survived in Eritrea under the British Administration (Rena 2007). The Banco di Napoli operated with a single branch in Asmara. The Banco di Roma's Eritrea branch network had four branch offices, two located in Asmara, one in Assab and one in Massawa; in 1960 a branch was opened in Addis Ababa.

On the other hand, the sphere of non-bank financial institutions included the Development Bank of Ethiopia (DBE), the Imperial Savings and Home Ownership Public Association (ISHOPA) and the Investment Bank of Ethiopia (IBE). The DBE belonged to the development banks category and had been set up in 1951 on the foundations of the Agricultural and Commercial Bank of Ethiopia. The ISHOPA had been constituted in 1962 following the model of American savings and loan associations. ${ }^{22}$ Lastly, a financial institution for industrial development had been founded in August 1963 with the name of Investment Bank of Ethiopia.

The State Bank of Ethiopia, since the beginning of its activity, had done a good job and had significantly contributed to the economic development of the country. However in the early nineteen-sixties the need to improve the financial system by modifying its structure become evident and IMF had supported this change with its advise. It was not a question of reorganizing a single bank, but rather of laying the foundations for a new financial and credit structure better suited to meeting the needs of the domestic economy at a given stage of

\footnotetext{
${ }^{22}$ According to Art. 4 of the statute: "the purpose of the Association, by which it shall be guided in all its actions, are to promote thrift by providing a convenient and safe method for people to save and invest their money and to provide for the sound and economic financing of the individual's ownership of his own residence".
} 
development (Drake 1980; Arndt 1983). In other words it was the case to bring in financial innovations (Bhatt 1995).

First of all in order to achieve a more advanced stage in the structure of the banking system it was necessary to move on to a two-tier system by splitting the State Bank of Ethiopia into two separate institutions, i.e. a pure central bank and a public-owned national commercial bank. Secondly other important changes were suggested also by political considerations. In fact, the end of the autonomous administration of Eritrea had posed a serious problem also in the banking sector. After this federated territory had become just another Ethiopian province, it was no longer acceptable to conceive different banking regulations from the rest of the country. It was thus necessary to choose between extending the public banking monopoly to Eritrea - with ensuing nationalization or winding up of the Italian banks' branches - or setting up a competitive free banking system in all the Ethiopian provinces. The second solution prevailed and banking market in Ethiopia was opened both to private national banks and to expatriate financial institutions. 
T A B L E S

Table 1

DATA FROM THE END-OF-THE YEAR BALANCE SHEETS

OF THE STATE BANK OF ETHIOPIA

(Unit: millions of Ethiopian dollars)

\begin{tabular}{|c|c|c|c|c|c|}
\hline Year & Total Assets $*$ & Net Capital & Expenditures & Receipts & Profit \\
\hline 1953 & 125.5 & 7.3 & 3.2 & 5.8 & 2.6 \\
\hline 1954 & 146.6 & 13.0 & 4.1 & 7.3 & 3.2 \\
\hline 1955 & 141.6 & 15.9 & 4.8 & 7.8 & 3.0 \\
\hline 1956 & 188.3 & 20.5 & 4.2 & 8.7 & 4.5 \\
\hline 1957 & 211.7 & 27.0 & 4.6 & 10.8 & 6.2 \\
\hline 1958 & 216.4 & 33.0 & 4.9 & 10.9 & 6.0 \\
\hline 1959 & 187.2 & 27.6 & 8.0 & 12.6 & 4.6 \\
\hline 1960 & 208.3 & 30.5 & 5.9 & 13.7 & 7.8 \\
\hline 1961 & 221.8 & 29.5 & 9.7 & 18.6 & 8.9 \\
\hline 1962 & 262.4 & 36.3 & 10.1 & 22.0 & 11.9 \\
\hline 1963 & 285.5 & 42.2 & 11.2 & 25.0 & 13.8
\end{tabular}

* Total assets refer solely to the SSB's Banking Department 
TABLE 2

STATE BANK OF ETHIOPIA DEPARTMENT $(*)$

(unit: millions of Ethiopian dollars)

\begin{tabular}{|c|c|c|c|c|}
\hline YEAR $\left.{ }^{* *}\right)$ & BANK-NOTES & COINS & TOTAL $\%$ & NOTES OF TOTAL \\
\hline $1945 \ldots$ & 23,6 & 6,6 & 30,2 & 78,1 \\
\hline $1946 \ldots$ & 39,9 & 14,5 & 54,4 & 73,3 \\
\hline $1947 \ldots$ & 37,4 & 27,8 & 65,2 & 57,4 \\
\hline $1948 \ldots$ & 42,4 & 28,8 & 71,2 & 59,6 \\
\hline $1949 \ldots$ & 40,4 & 29,4 & 69,8 & 57,9 \\
\hline $1950 \ldots$ & 52,9 & 30,4 & 83,3 & 63,5 \\
\hline $1951 \ldots$ & 75,6 & 33 & 108,6 & 69,6 \\
\hline $1952 \ldots$ & 90,6 & 30,9 & 121,5 & 74,6 \\
\hline $1953 \ldots$ & 102,8 & 32,8 & 135,6 & 75,8 \\
\hline $1954 \ldots$ & 115,7 & 35,2 & 150,9 & 76,7 \\
\hline $1955 \ldots$ & 126,3 & 35,8 & 162,1 & 77,9 \\
\hline $1956 \ldots$ & 129,1 & 35,9 & 165 & 78,2 \\
\hline $1957 \ldots$ & 134,4 & 36,8 & 171,2 & 78,5 \\
\hline $1958 \ldots$ & 124,6 & 37,9 & 162,5 & 76,7 \\
\hline $1959 \ldots$ & 126,8 & 38,4 & 165,2 & 76,7 \\
\hline $1960 \ldots$ & 134,7 & 39,4 & 174,1 & 77,4 \\
\hline $1961 \ldots$ & 147,5 & 39,9 & 187,4 & 78,7 \\
\hline $1962 \ldots$ & 156,4 & 41 & 197,4 & 79,2 \\
\hline $1963 \ldots$ & 168,5 & 43,1 & 211,6 & 79,6 \\
\hline
\end{tabular}

* Compilation of data gathered from the Annual Reports of the State Bank of Ethiopia and from Economic Conditions and Market Trends. 
TABLE 3

MAKE UP THE BACKING FUND FOR ISSUE OF BANK-NOTES (*) (unit: millions of Ethiopian dollars)

\begin{tabular}{|c|c|c|c|c|c|c|c|}
\hline YEAR & GOLD & SILVER & $\begin{array}{c}\text { FOREIGN } \\
\text { CURRENCY } \\
\text { RESERVE }\end{array}$ & $\begin{array}{c}\text { TOTAL } \\
\text { METAL \& } \\
\text { CURRENCY } \\
\text { RESERVES }\end{array}$ & \% BACKING & $\begin{array}{c}\text { ETHIOPIAN } \\
\text { TREASURY } \\
\text { BONDS }\end{array}$ & TOTAL \\
\hline 1956 & 9,5 & 15,4 & 17,2 & 42,1 & 32,6 & 87 & 129,1 \\
\hline 1957 & 9,5 & 15,6 & 22,3 & 47,4 & 35,3 & 87 & 134,4 \\
\hline 1958 & 9,6 & 15,6 & 41,4 & 66,6 & 53,5 & 87 & 124,6 \\
\hline 1959 & 8,4 & 15,6 & 25,8 & 39,8 & 31,4 & 87 & 126,8 \\
\hline 1960 & 7,4 & 5,7 & 34,6 & 47,7 & 35,4 & 87 & 134,7 \\
\hline 1961 & 8,3 & 5,7 & 42,5 & 56,5 & 38,3 & 91 & 147,5 \\
\hline 1962 & 7,3 & 5,7 & 52,4 & 65,4 & 41,8 & 91 & 156,4 \\
\hline 1963 & 6,1 & 3,4 & 68 & 77,5 & 46 & 91 & 168,5 \\
\hline
\end{tabular}

* Data taken from the balances of the Issue Department of the State Bank of Ethiopia and the Ethiopia Statistical Abstract, drawn up by the author. 
TABLE ‘

OVERALL VOLUME AND QUALITATIVE MAKE UP OF STOCK OF MONEY $\left(^{*}\right)$ (figures as at 31 st december of each year)

\begin{tabular}{|c|c|c|c|c|c|c|c}
\hline YEAR & $\begin{array}{c}\text { CASH ON } \\
\text { HAND AT SBE } \\
\text { BANKING } \\
\text { DEPARTMENT }\end{array}$ & $\begin{array}{c}\text { ACTUAL } \\
\text { CIRCULATION } \\
\text { OF BANK- } \\
\text { NUTES \& } \\
\text { COINS }\end{array}$ & $\begin{array}{c}\text { PRIVATE } \\
\text { CURRENT } \\
\text { ACCOUNTS } \\
\text { AT THE } \\
\text { SBE }\end{array}$ & $\begin{array}{c}\text { CURRENT } \\
\text { ACCOUNTS } \\
\text { AT OTHER } \\
\text { BANKS?? } \\
\text { NET OF } \\
\text { CASH ON } \\
\text { HAND }\end{array}$ & $\begin{array}{c}\text { STOCK } \\
\text { OF } \\
\text { MONEY }\end{array}$ & $\begin{array}{c}\text { SHARE } \\
\text { OF } \\
\text { BANK- } \\
\text { NOTES } \\
\text { \& } \\
\text { COINS }\end{array}$ & $\begin{array}{c}\% \\
\text { SHARE } \\
\text { OF } \\
\text { DEPOS } \\
\text { MONE }\end{array}$ \\
\hline 1948 & 8,6 & 62,6 & 18,4 & - & 81 & 77,3 & 22,7 \\
\hline 1949 & 7,2 & 62,6 & 17,7 & - & 80,3 & 77,9 & 22,1 \\
\hline 1950 & 10,3 & 73 & 22,1 & - & 95,1 & 76,8 & 23,2 \\
\hline 1951 & 21,6 & 87 & 17,7 & - & 104,7 & 83,1 & 16,9 \\
\hline 1952 & 28,9 & 92,6 & 23,6 & 0,4 & 116,6 & 79,4 & 20,6 \\
\hline 1953 & 21,5 & 114,1 & 28 & 1,4 & 143,5 & 79,5 & 20,5 \\
\hline 1954 & 32,6 & 118,3 & 23 & 1,3 & 142,6 & 83 & 17 \\
\hline 1955 & 33,8 & 128,3 & 29,6 & 2,7 & 160,6 & 79,9 & 20,1 \\
\hline 1956 & 31,5 & 133,5 & 37,8 & 6,6 & 177,9 & 75 & 25 \\
\hline 1957 & 26,9 & 144,3 & 46,3 & 8,2 & 198,8 & 72,6 & 27,4 \\
\hline 1958 & 23,4 & 139,1 & 53 & 8,4 & 200,5 & 69,4 & 30,6 \\
\hline 1959 & 19,5 & 145,7 & 46,2 & 11,4 & 203,3 & 71,7 & 28,3 \\
\hline 1960 & 18,5 & 155,6 & 57,3 & 10,2 & 223,1 & 69,7 & 30,3 \\
\hline 1961 & 20,2 & 167,2 & 60,5 & 13,1 & 240,8 & 69,4 & 30,6 \\
\hline 1962 & 16,8 & 180,6 & 60,4 & 14 & 255 & 70,8 & 29,2 \\
\hline 1963 & 18,3 & 193,3 & 64,8 & 15,6 & 273,7 & 70,6 & 29,4 \\
\hline
\end{tabular}

${ }^{*}$ Figures shown are in millions of Ethiopian dollars. 
TABLE

5

DEPOSITS AND LOAN INVESTMENTS OF THE STATE BANK OF ETHIOPIA

DURING THE 1945-1956 PERIOD

(unit: millions of Ethiopian dollars)

\begin{tabular}{|c|c|c|c|}
\hline YEAR * & DEPOSITS & LOANS & $\begin{array}{c}\text { \% RATIO LOANS TO } \\
\text { DEPOSITS }\end{array}$ \\
\hline 1945 & 23 & 8,9 & 36,7 \\
\hline 1946 & 36,6 & 17,5 & 47,8 \\
\hline 1947 & 28,8 & 19,6 & 68,1 \\
\hline 1948 & 30 & 17,9 & 59,7 \\
\hline 1949 & 29,7 & 24,7 & 83,2 \\
\hline 1950 & 43,2 & 18,9 & 43,7 \\
\hline 1951 & 45,2 & 10,9 & 24,1 \\
\hline 1952 & 58,3 & 24,5 & 42 \\
\hline 1953 & 103,8 & 19,6 & 18,9 \\
\hline 1954 & 115,6 & 21,7 & 18,8 \\
\hline 1956 & 152,9 & 41,1 & 26,9 \\
\hline
\end{tabular}

* Situation as at 31st December. 
TABLE 6

DEPOSITS AT THE STATE BANK OF ETHIOPIA DURING THE 1958-1963 * PERIOD

(amount at the end of year)

\begin{tabular}{|c|c|c|c|c|c|c|c|c|c|c|c|c|c|c|}
\hline YEAR & \multicolumn{2}{|c|}{1957} & \multicolumn{2}{|c|}{1958} & \multicolumn{2}{|c|}{1959} & \multicolumn{2}{|c|}{1960} & \multicolumn{2}{|c|}{1961} & \multicolumn{2}{|c|}{1962} & \multicolumn{2}{|c|}{1963} \\
\hline CATEGORY & $\begin{array}{l}\text { Thou.of } \\
\text { Eth. \$ }\end{array}$ & $\%$ & $\begin{array}{l}\text { Thou.of } \\
\text { Eth. } \$\end{array}$ & $\%$ & $\begin{array}{l}\text { Thou.of } \\
\text { Eth. \$ }\end{array}$ & $\%$ & $\begin{array}{l}\text { Thou. of } \\
\text { Eth. \$ }\end{array}$ & $\%$ & $\begin{array}{l}\text { Thou.of } \\
\text { Eth. \$ }\end{array}$ & $\%$ & $\begin{array}{l}\text { Thou.of } \\
\text { Eth. \$ }\end{array}$ & $\%$ & $\begin{array}{l}\text { Thou. of } \\
\text { Eth. \$ }\end{array}$ & $\%$ \\
\hline $\begin{array}{c}\text { Current Account } \\
\text { of Treasury \& } \\
\text { deposits of Public } \\
\text { Agencies }\end{array}$ & 103.612 & 57,7 & 89.687 & 54,6 & 75.554 & 51,7 & 74.822 & 46,3 & 77.921 & 45,5 & 93.119 & 47,4 & 78.497 & 39.7 \\
\hline $\begin{array}{c}\text { Credit concerns in } \\
\text { Ethiopia }\end{array}$ & 4.500 & 2,5 & 4.630 & 2,8 & 2.181 & 1,5 & 1.265 & 0,8 & 1.781 & 1 & 490 & 0,2 & 2.353 & 1.2 \\
\hline $\begin{array}{c}\text { Foreign } \\
\text { Correspondents }\end{array}$ & 1.592 & 0,9 & 1.725 & 1 & 406 & 0,3 & 2.994 & 1,8 & 1.389 & 0,8 & 4.129 & 2,1 & 4.319 & 2.2 \\
\hline $\begin{array}{l}\text { Deposits in } \\
\text { current accts. and } \\
\text { various creditors }\end{array}$ & 48.591 & 27 & 51.336 & 31,2 & 46.441 & 31,8 & 58.182 & 35,9 & 60.283 & 35,2 & 60.869 & 31 & 69.005 & 34.8 \\
\hline $\begin{array}{l}\text { Fixed-term } \\
\text { deposit }\end{array}$ & 14.313 & 8 & 7.854 & 4,8 & 10.544 & 7,2 & 9.465 & 5,8 & 11.486 & 6,7 & 15.741 & 8 & 14.862 & 7.5 \\
\hline Savings deposits & 7.055 & 3,9 & 9.087 & 5,6 & 10.940 & 7,5 & 15.137 & 9,4 & 18.511 & 10,8 & 22.283 & 1,3 & 28.852 & 14.6 \\
\hline Total & 179.663 & 100 & 164.319 & 100 & 146.066 & 100 & 161.865 & 100 & 171.371 & 100 & 196.631 & 100 & 197.888 & 100 \\
\hline
\end{tabular}

* Data taken from the Annual Reports of the State Bank of Ethiopia and the Ethiopian Observer, No.5, 1965, drawn up by the author. 
Table 7

TRENDS IN DEPOSITS AT THE STATE BANK OF ETHIOPIA 1957=100 * (Sum at end of year)

\begin{tabular}{|c|c|c|c|c|c|c|c|}
\hline YEAR & $\begin{array}{c}\text { Current } \\
\text { accounts of } \\
\text { Treasury and } \\
\text { deposits of } \\
\text { Public } \\
\text { Agencies }\end{array}$ & $\begin{array}{c}\text { Credit } \\
\text { concerns } \\
\text { in } \\
\text { Ethiopia }\end{array}$ & $\begin{array}{c}\text { Foreign } \\
\text { Correspondents }\end{array}$ & $\begin{array}{c}\text { Deposits } \\
\text { in } \\
\text { current } \\
\text { accounts } \\
\text { and } \\
\text { various } \\
\text { creditors }\end{array}$ & $\begin{array}{c}\text { Fixed } \\
\text { term } \\
\text { deposits }\end{array}$ & $\begin{array}{c}\text { Savings } \\
\text { deposits }\end{array}$ & $\begin{array}{c}\text { Sum } \\
\text { total of } \\
\text { deposits }\end{array}$ \\
\hline 1957 & 100 & 100 & 100 & 100 & 100 & 100 & 100 \\
\hline 1958 & 86,6 & 102,9 & 108,3 & 106,6 & 54,9 & 128,8 & 91,5 \\
\hline 1959 & 72,9 & 48,5 & 25,5 & 95,6 & 73,7 & 155,1 & 81,3 \\
\hline 1960 & 72,2 & 28,1 & 188,1 & 119,7 & 66,1 & 214,6 & 90,1 \\
\hline 1961 & 75,2 & 39,6 & 87,2 & 124,1 & 80,2 & 262,4 & 95,4 \\
\hline 1962 & 89,9 & 10,9 & 259,4 & 125,3 & 110 & 315,8 & 109,4 \\
\hline 1963 & 75,8 & 52,3 & 271,3 & 142 & 103,8 & 409 & 110,1 \\
\hline
\end{tabular}

* Data taken from the Annual Reports of the State Bank of Ethiopia and the Ethiopian Observer, No4, 1965, drawn up by the author. 
STATE BANK OF ETHIOPIA INVESTMENTS DURING THE 1958

(End-of-year situation)

\begin{tabular}{|c|c|c|c|c|c|c|c|c|}
\hline YEAR & \multicolumn{2}{|c|}{1957} & \multicolumn{2}{|c|}{1958} & \multicolumn{2}{|c|}{1959} & \multicolumn{2}{|c|}{1960} \\
\hline CATEGORY & A & B & A & B & A & B & A & B \\
\hline $\begin{array}{l}\text { Building } \\
\text { Credit }\end{array}$ & 7.216 & 28,3 & 7.656 & 21,6 & 9.406 & 18,2 & 11.836 & 17,8 \\
\hline $\begin{array}{l}\text { Other } \\
\text { Mortgage } \\
\text { credit }\end{array}$ & 2.236 & 8,8 & 3.686 & 10,4 & 4.362 & 8,4 & 5.059 & 7,6 \\
\hline $\begin{array}{l}\text { Personal } \\
\text { loans }\end{array}$ & 1.438 & 5,6 & 1.600 & 4,5 & 1.497 & 2,9 & 1.402 & 2,1 \\
\hline $\begin{array}{l}\text { Advances } \\
\text { on } \\
\text { securities }\end{array}$ & - & - & 25 & 0,1 & 620 & 0,1 & 380 & 0,6 \\
\hline $\begin{array}{l}\text { Commerce } \\
\text { credits }\end{array}$ & 4.271 & 16,7 & 6.673 & 18,8 & 7.059 & 13,6 & 9.316 & 14 \\
\hline $\begin{array}{l}\text { Advances } \\
\text { on } \\
\text { merchandis } \\
\text { e }\end{array}$ & 3.274 & 12,8 & 2.551 & 7,2 & 4.029 & 7,3 & 4.150 & 6,2 \\
\hline Export finance & 187 & 0,7 & 194 & 0,6 & 532 & 1 & 397 & 0,6 \\
\hline $\begin{array}{l}\text { Active current } \\
\text { accounts }\end{array}$ & 4.676 & 22,3 & 10.827 & 30,6 & 19.912 & 36,6 & 26.519 & 39,8 \\
\hline $\begin{array}{l}\text { Investments in } \\
\text { securities }\end{array}$ & 1.220 & 4,8 & 2.200 & 6,2 & 5.405 & 10,4 & 7.539 & 11,3 \\
\hline Total & 25.518 & 100 & 35.412 & 100 & 51.822 & 100 & 66.598 & 100 \\
\hline
\end{tabular}

( $A=$ In millions of Ethiopian dollars; $B=\ln \%$ )

- Data refer exclusively to credit transactions for financing the private sector and for investments in stock securites. The transactions of the Reports of the State Bank of Ethiopia and Ethiopian Observer, No 4, 1965. 
TRENDS IN DEPOSITS AT THE STATE BANK OF ETHIOPIA 1957=100 *

\begin{tabular}{|c|c|c|c|c|c|c|c|}
\hline & \multicolumn{7}{|c|}{ YEAR } \\
\hline & 1957 & 1958 & 1959 & 1960 & 1961 & 1962 & 1963 \\
\hline CLASS OF TRANSACTION & & & & & & & \\
\hline Building credit & 100 & 106,1 & 130,3 & 164 & 193,3 & 193,6 & 190,2 \\
\hline Other Mortage credit & 100 & 164,8 & 195,1 & 226,3 & 246,2 & 259,8 & 306,2 \\
\hline Personal loans & 100 & 111,3 & 104,1 & 97,5 & 100,3 & 99,7 & 101,5 \\
\hline Advances on securities & - & 100 & 2.480 & 1.520 & 2808 & 3092 & 4156 \\
\hline Commerce credits & 100 & 156,2 & 165,3 & 218,1 & 269,1 & 374,9 & 467,1 \\
\hline Advances on merchandise & 100 & 77,9 & 123,1 & 126,8 & 118 & 242,2 & 242,6 \\
\hline Export finance & 100 & 103,7 & 284,5 & 212,3 & 391,4 & 318,2 & 483,9 \\
\hline Active current accounts & 100 & 190,8 & 333,2 & 467,2 & 597,9 & 710,5 & 781,2 \\
\hline Investments in securities & 100 & 180,3 & 443 & 617,9 & 658,5 & 771,1 & 638,2 \\
\hline Total & 100 & 138,8 & 203,1 & 261 & 312,2 & 377,2 & 407,5 \\
\hline
\end{tabular}

* Base:end-of-year 1957, with the exception of "Advances on Securities" for which 1958 was taken as base year. 


\section{BIBLIOGRAPHY}

ARNDT H. W. (1983), „Financial Development in Asia“, Asian Development Review, Vol. I, n. 1

BATHA M., S. GRYZIEWICZ \& L. TICKEHER (1965), “An Outline of the Fiscal System in Ethiopia”, Ethiopia Observer, n. 4, 1965.

BHATT V.V.(1995), Financial Systems, Innovations and Development, Sage Publications, New Delhy 1995.

BERTONE M. (1936), "Il problema monetario dell'Etiopia italiana", Il Sole, 25th and 26th July 1936.

CASELLI C. \& A. MAURI (1986), Moneta e banca in Etiopia, Finafrica, Giuffrè, Milano 1986.

DEGUEFE T. (1965), “Credit Institutions in Ethiopia”, Ethiopia Observer, n. 4, 1965.

DEGUEFE T. (2006), Minutes of an Ethiopian Century, Shama Books, Addis Ababa, 2006.

DELL'AMORE (ed.), Banking Systems in Africa, Finafrica, Milano 1971.

DE KOCK M.H. (1974), Central Banking, Crosby Lockwood Staples, London 1974.

DE ROSA G. (1984), Storia del Banco di Roma, Vol. III, Banco di Roma, Roma 1984.

DRAKE P.J. (1980), Money, Finance and Development, Martin Robertson, Oxford 1980.

DRAKE P.J. (2004), Currency, Credit and Commerce, Ashgate Publishing Ltd., Aldershot 2004.

FORBES MUNRO J. (1976), Africa and the International Economy 1800-1960, J.M. Dent \& Sons, London 1976.

FRY M.J., C.A.E. GOODHART, A. ALMEIDA (1996), Central Banking in Developing Countries, Routledge, London 1996.

KONCZACKI Z.A. (1962), "Currency and Banking in Ethiopia", The South African Journal of Economics, September 1962.

MAREIN N. (1955), The Ethiopian Empire Federation and Laws, Royal Netherlands Printing and Lithographic Company, Rotterdam 1955.

MAURI A. (1967), Il mercato del credito in Etiopia, Giuffrè, Milano 1967.

MAURI A. (1971), "Ethiopia", G. DELL'AMORE (ed.), Banking Systems in Africa, Finafrica, Milano 1971.

MAURI A. (1997), "The Rise of Banking in Ethiopia", African Review of Money, Finance and Banking, n. 1-2, 1007. 
MAURI A. (2003), "The Early Development of Banking in Ethiopia", RISEC - International Review of Economics and Business, Vol. L, n. 4, December 2003.

MAURI A. (2007), L'East African Currency Board e la genesi dell'attività bancaria nell'Africa Orientale Britannica, Department of Economics, Business and Statistics, Università degli Studi di Milano, Working Paper 10-2007..

OANNOU J. (1961), “L'Ethiopie et son économie", Revue de la Société d'Etudes et d'Expansion, November-December 1961.

PAGE S. \& J.HEALEY (1993), «The Financial Sector », PAGE S. (ed.) Monetary Policy in Developing Countries, Routledge, London 1993.

PANKHURST R. (1965), "The History of Currency and Banking in Ethiopia and the Horn of Africa from the Middle Ages to 1935”, Ethiopia Observer, n. 4, 1965.

PARISI A. (1938), "Problemi creditizi dell'Impero", Rassegna Economica dell'Africa Italiana, April 1938.

PERHAM M. (1949), The Government of Ethiopia, Faber \& Faber Ltd., $2^{\text {nd }}$ printing London 1949.

RENA R. (2007), "Historical Development of Money and Banking in Eritrea from the Axumite Kingdom to the Present", African and Asian Studies, n. 6, 2007.

REY C. (1923), Unconquered Abyssinia, Seley Service \& Co., London 1923.

ROTHROCK J.B. (1947), “The State Bank in Ethiopian Economy”, New Times and Ethiopia News, September 1947.

SCHAEFER C. (1992), "The Politics of Banking: the Bank of Abyssinia (1905-1931)", International Journal of African Historical Studies, Vol. 25, n. 2, 1992.

STATE BANK OF ETHIOPIA, Annual Report, various years.

STATE BANK OF ETHIOPIA, Report on Economic Conditions and Market Trends, various years.

TSCHOEGL A.E. (2001), "Maria Theresa's Thaler: a Case of International Money", Eastern Economic Journal”, 27 (4) 2001.

TUCCIMEI E. (1999), La Banca d'Italia in Africa. Introduzione all'attività dell'istituto di emissione nelle colonie dall'età Crispina alla seconda guerra mondiale, Vol. VIII, Collana storica della Banca d'Italia, Laterza, Bari 1999.

VESTAL T.M. (1999), Ethiopia: a Post-Cold War African State, Praeger, Westport CT, 1999.

ZEWDE B, (1991), A History of Modern Ethiopia 1855-1974, Addis Ababa University Press, Addis Ababa 1991. 